\title{
Revitalizing a Mentoring Program for Academic Librarians
}

\section{Diana Farmer, Marcia Stockham, and Alice Trussell}

\begin{abstract}
Many new employees naturally seek out coworkers and informal advisors as a way of learning about their new positions and organizations. However, a formalized mentoring program is a way to meet the needs of new employees and effectively impart the information and advice in a coordinated, ongoing process. This paper focuses on the process of revitalizing a formalized mentoring program in an academic library. Included are details of the process developed by one institution, an extensive bibliography, sample checklists, and assessment tools.
\end{abstract}

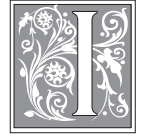

ndividuals embarking on a new professional position bring with them a wide range of professional skills and experiences. Some are fresh out of a degree program, and others have worked in the profession for many years in varying capacities. However, all individuals starting a new position can use help in getting to know the specific expectations, routines, standards, and organizational culture. Many new employees naturally seek out coworkers and informal advisors as a way of learning about the new position and the surrounding organization. Unfortunately, the informal method leads to a patchwork of input of varying effectiveness. A formalized mentoring program can meet the needs of the new employees and more effectively impart the information and advice in a coordinated, ongoing process.

Since it is acknowledged that mentoring can be delivered in a wide variety of ways, how does an organization go about developing an effective program that fits the needs of the institution and individuals? This paper describes the process and evaluation of revitalizing a mentoring program at K-State Libraries (KSL).

\section{Background/History}

Kansas State University is a land-grant institution with approximately 23,000 students. Tenure-track librarians have faculty status, at the ranks of assistant professor, associate professor, or professor. There is a rich history of K-State librarians as faculty.

There has been a formalized mentoring program at the K-State Libraries for about 20 years. The main purpose for the program was to guide junior faculty through the promotion and tenure process, with one of the key responsibilities being to help pretenured faculty members prepare their portfolios for an annual

Diana Farmer is an Associate Professor and Science Librarian at Hale Library of Kansas State University; email:dmfarmer@ksu.edu. Marcia Stockham is an Associate Professor and Chair, Social Sciences/Humanities Dept. at Hale Library of Kansas State University; email: stockham@ksu.edu. Alice Trussell is an Associate Professor and Engineering Librarian at Fiedler Engineering Library of Kansas State University; email:alitrus@ksu.edu. 
review. This program required that each tenured faculty member be assigned to one or more pretenured faculty in a mentoring relationship. There were loose guidelines suggesting topics each mentor should "cover" with the new faculty member, and care was taken to ensure that the mentor and mentee were from different departments within the library. This arrangement was followed to allow confidentiality in the relationship and a safe environment to discuss issues that the new hire did not want to discuss with his department or supervisor. The level of relationship development and mentoring activities were left up to each faculty member, since there were no standards or expectations for activities between mentor and mentee.

As the program aged, it was obvious that the level of mentoring was inconsistent. Some pairs had very good relationships that were truly meeting the needs of the mentee and were rewarding for the mentor. Other pairs had mentors who did not necessarily have the time or inclination to provide adequate mentoring, and the result was frustration for both parties. In 2004, there were fifteen tenured and sixteen pretenured faculty participating in the mandatory mentoring program when the Professional Development Committee (PDC) of the Libraries Faculty Association decided to revise and improve it. The PDC embarked on a literature review and a series of meetings focused on restructuring and redesign.

\section{Literature Review}

The initial review of the literature was limited to library science databases, indexes, and abstracts. The search was further limited to starting or revitalizing mentoring programs in academic libraries for the primary purpose of promotion and tenure. This resulted in a limited number of articles. The two most useful were those by Annalisa R.Van Avery ${ }^{1}$ at the University of Albany and Lois Kuyper-Rushing ${ }^{2}$ at Louisiana State University. Van Avery primarily discussed the difficulties of getting promotion and tenure criteria accepted, and the article attachments influenced our revised documents. Kuyper-Rushing provided a step-by-step process for setting up a program and included what she said were previously undocumented parts of a program. Basic concepts that we adopted from these articles included the following:

- Mentors should be volunteers.

- Activities should include group events.

- The pairs should not be from the same department.

- Mentoring should be focused on the service, research, and creative activities of the mentee.

- Assessment and adjustment of the program should occur regularly.

Most of the retrieved articles focused primarily on the issues of faculty status and tenure for librarians at academic institutions. Many articles discussed informal mentoring within the profession, while others discussed formal mentoring programs sponsored by professional organizations (such as ALA, ACRL, SLA, and AALL). There were also a growing number of articles on fostering leadership within the profession through mentoring. These articles emphasized the need to encourage "new" librarians to develop skills and explore ideas outside the traditional role of librarians. Two articles on this topic that influenced the philosophy of the program developed at K-State Libraries were those by Linda Marie Golian-Lui ${ }^{3}$ and Harriet Swain. ${ }^{4}$ Both articles advocated mentoring that developed careers different from the careers of the mentors. Swain discussed the need to respect individual work styles and encourage mentees to develop research ideas, including opportunities for collaboration. Golian-Lui stated that, ideally, successful mentoring is about exercising good leadership skills, challenging both mentor and mentee and creating a cycle of support.

While the library literature was helpful in identifying many of the elements needed for successful mentoring relation- 
ships, little additional information on establishing or revitalizing a program in an academic institution was found. Nor did the library literature identify and describe the skills necessary to be an effective mentor or how to keep a program vital for both mentors and mentees.

At this point, the literature search was broadened to include literature in the education, management, human resources, career development and youth counseling disciplines. The broadened search resulted in retrieval of the desired information, including program establishment, mentoring skills, program evaluation, establishing benchmarks, and use of group mentoring.

The Web was also searched for information about mentoring programs, both institutionwide and in academic libraries. An excellent resource, the comprehensive EDUCAUSE Mentoring Information Kit, was located in this search. All sites consulted are included in the literature review bibliography. (See Appendix A.)

\section{Revitalized Program}

Prior to efforts to revitalize the program, the responsibilities of the Professional Development Committee were minimal. Committee activities in the mentoring program were to assign a mentor to each new hire and to offer a "tenure workshop" at the beginning of each academic year. That fall, the committee changed the format and content of the tenure workshop. The success of the updated workshop encouraged the committee to continue their plans to revitalize the mentoring program. The PDC developed the framework for a more structured mentoring program.

The draft proposal subsequently presented to the library faculty included the following major changes:

- Mentors should be volunteers-faculty members who have a real interest and commitment in helping junior faculty grow professionally. There was a risk that this revision could result in a shortage of mentors, but the committee felt it was important that mentors be actively involved rather than viewing mentoring as an "assignment."

- The committee changed the program focus from "attaining tenure" and guidance through that process, to development of the person in all aspects of professional life. The committee felt strongly that this type of relationship would be more rewarding for both the mentor and the person being mentored.

- Every effort would be made to match pairs with similar interests and/or complementary strengths and weaknesses. The new guidelines included a timeline for determining the best match.

- Written guidelines, which included regular meetings and relationship expectations, were made available as support for the mentors. The committee knew that these guidelines would meet resistance from long-time mentors simply because change can be difficult.

- Each person in the program would be free to ask the committee for reassignment without guilt if the relationship was not deemed productive or circumstances changed for either member. Requests for changes had happened occasionally in the past, but both parties often felt awkward, and some pairs chose to continue in a deteriorating or less than helpful relationship.

The documentation for the revised mentoring program consisted of an outline for the new program, criteria for mentors, responsibilities of both mentors and mentees, timelines, suggested and encouraged activities for the pair, a bibliography, and the role of the supervisor in the mentoring program. Prior to presentation of the draft program to the library faculty, the PDC asked a newly formed mentoring pair to conduct a threemonth trial following the draft guidelines and documents. The feedback from the pair was positive and incorporated into the proposal presentation. The committee presented the documents to the library faculty at a session that allowed for thorough discussion of the principles 
and the rationales behind the concepts. Concerns of the faculty resulted in more clearly defining the role of the mentee's immediate supervisor as well as other specific language changes in order to reach consensus on the documents. Appendices B.1-B.7 reflect the version of the documents approved at the faculty meeting. As expected, those who had served longest as mentors expressed the most doubts about the significant changes in the program.

Virtually all faculty members agreed that compulsion can create resentment and apathy in certain individuals, resulting in ineffective mentoring. Therefore, there was agreement that mentoring should not be a requirement imposed upon all tenured faculty members.

Shortly after the adoption of the documents, the current tenured faculty members were given the option of volunteering to be a mentor under the new guidelines. This process resulted in a few members opting out. The mentees and mentors who were in an established relationship were encouraged to use the practices outlined in the new documents. The speed of adoption and effectiveness varied according to the commitment of the pair and the inclination to actually adapt to the suggested guidelines.

The PDC initiated quarterly meetings of mentees and mentors to secure feedback from members of each group. The groups met separately to encourage candid conversation about what was and what wasn't working as well as expected. Information gained from the sessions helped guide incremental improvements in encouraged practices and also served to clarify confusing interpretations. For example, one of the original guidelines was for the mentor and mentee to establish goals for their relationship. Because KSL also requires goal-setting as part of performance expectations, some individuals presumed they should be the same goals. Much of this confusion was resolved by the PDC giving examples of appropriate goals for the mentoring relationship (one example would regularly scheduled meetings).

In the two to three years prior to the implementation of the rejuvenated mentoring program, budgetary constraints, coupled with the transition to a new Dean of Libraries, resulted in faculty vacancies that were not filled. With the new Dean's encouragement and an improved budget, hiring began for these vacancies as well as for newly created positions. Since the new guidelines called for no mentor to have more than two mentees, the numbers of new faculty made it impossible to find enough volunteers in the fall of 2005. As a result, the PDC implemented group mentoring as a new tactic for the new employees. During their first year, the new employees were part of a group mentored by the senior member of the Professional Development Committee. The group mentor developed a series of five sessions to cover the basic information the mentee would need about the university, the KSL, and the differences in practices from those at other institutions. The group mentoring turned out to be very successful. The new mentees had an enhanced opportunity to communicate with each other as well as to have regular meetings with the group mentor. Following the first academic year of group mentoring, the mentees were then assigned individual mentors. This was possible in the fall of 2006 because more tenured faculty volunteered to be mentors.

\section{Analysis}

Feedback from both mentors and mentees suggests that the enhanced mentoring program has been a success. Documentation of expectations has provided more structure for both parties. The transition to using only faculty who actually desired to be a mentor has resulted in more positive activities and interactions between the pair.

Following the first year of the program, the PDC conducted formal surveys to gauge the progress of the revitalization efforts. (See Appendices C.1-C.3.) 


\section{Mentor Feedback}

The relationship profile questionnaire showed that mentors felt they had acted in the following roles:

- advisor

- advocate

- resource

Strengths of the relationship mentioned most often by mentors were these:

- established a good relationship

- mentee feels free to ask questions

- it is a two-sided relationship

- mentee is willing to follow suggestions

- there is open and honest communication

Items listed as weaknesses of the relationship included the following:

- never really developed a relationship

- mentee does not seek advice

- too busy to devote the desired time

- mentee only wants to discuss tenure and promotion process

Mentors listed the following as outcomes of the relationship:

- publications

- presentation/poster at professional conferences

- conducting research

- service activities

\section{Mentee Feedback}

The survey on mentoring effectiveness revealed that most mentees either agreed or strongly agreed that their mentor was effective in such areas as:

- accessibility

- professional integrity

- approachability

- supportiveness

- answering questions

- offering constructive criticism

Mentors were seen as counselors, advocates, advisors, and resources. There was reportedly frequent communication between the pair.

Strengths of the relationship perceived by mentees included such comments as:

- had meaningful, relevant discussions
- mentor was encouraging

- mentor was willing to advise and offer guidance

- mentor was honest

- mentor was willing to meet when contacted

- mentor truly cares about mentee's continued professional development.

The weaknesses of the relationship most frequently stated by mentees included:

- time constraints and conflicting schedules

- mentor not proactive

- did not communicate tenure committee's comments well

Mentees listed the same relationship outcomes as did the mentors.

As part of the continuing assessment, the PDC consulted with a professor in the College of Education who specializes in corporate/employee-centered training and participation in adult education. He gave a presentation to the library faculty about mentoring in general and offered specific suggestions to have a successful program. As a follow-up to the presentation, he met with the PDC to offer insight regarding future plans and to review his analysis of the surveys.

The effectiveness of group mentoring was discussed at a meeting of all mentees after completion of the first year of group mentoring. The mentees deemed group mentoring to be beneficial because they were learning together, hearing the same information, and meeting a variety of other faculty who presented at/participated in group mentor meetings. Questions from one person were answered for the benefit of all and often brought up topics that others had not considered at the time. In the spring of 2007, the current PDC realized that new faculty members who have worked in their positions for nearly a year have different questions and needs than those who are newly hired. As a result, the second class of group mentees was divided into two cohorts.

As the need for group mentoring diminishes because of fewer new hires 
and more volunteer mentors, lessons learned from the group experience will be incorporated into the regular mentoring guidelines.

\section{Conclusion}

Even though the revitalization of the KSL mentoring program was accomplished with broad, sweeping changes to the basic structure and perspective of the program, incremental changes and adjustments are necessary to keep the program vital. Faculty discussion surrounding the proposed changes helped heighten awareness and increase individual commitment to the process of mentoring. The membership of the PDC rotates, with overlapping terms to provide continuity. The current guidelines emphasize the importance of continuous assessment and feedback to determine strengths and weaknesses of the program. Adherence to the guidelines, along with the flexibility to make improvements, will ensure the vitality of the program.

After working with the new guidelines, it is clear that the majority of the KSL faculty would not be comfortable returning to the old system of mandatory mentoring responsibilities, minimal guidelines, and no real accountability for effective mentoring. Most important, our mentees are clearly receiving far more meaningful mentoring than has been the norm in the past.

\section{Notes}

1. Annalisa R. Van Avery, "Facing Personal Evaluation: A Mentoring Program Supports Professional Staff Undergoing Tenure Review," Reference Librarian 38 (1992): 121-31.

2. Lois Kuyper-Rushing, "Formal Mentoring Program in a University Library: Components of a Successful Experiment," Journal of Academic Librarianship 27:6 (Nov. 2001): 440-46.

3. Golian-Lui, Linda Marie, "Fostering Librarian Leadership through Mentoring," Adult Learning 14:1 (Winter 2003): 26.

4. Harriet Swain, "Develop a Career-Not a Clone," Times Higher Education Supplement 1699 (July 8, 2005): 58. 


\section{Appendix A. Literature Review Bibliography}

Library Mentor: Networking, Cooperation, Collaborations, Opportunity. http://wulibraries. typepad.com/mentor/ ed.Washington University Libraries, 2007.

"Peer Resources-Starting and Maintaining Mentoring." Peer Resources. Available online at www.mentors.ca/mentor.html. [Accessed 13 August 2004].

"SCOPA Mentoring Program for the Yale University Library." Yale University Library. Available online at www.library.yale.edu/scopa/mentoring/mentoring.html. [Accessed 13 August 2004].

“CUL CPD's Mentorship Program." Committee on Professional Development, Cornell University Library. Available online at www.library.cornell.edu/pdc/Mentor.html. [Accessed 13 August 13, 2004].

"Leadership Development Mentoring Program." Florida Library Association. Available online at http://flalib.org/committees/mentoring.html. [Accessed 13 August 2004]. Link no longer active July 2007.

“Library Faculty Mentoring Program." University of Southern California Libraries. Available online at www.usc.edu/isd/about/faculty/mentoringpolicy.html. [Accessed 13 August 2004].

“Editorial: Improving Quality." Journal of Academic Librarianship 22, no. 6 (Nov. 1996, 1996): 421-22.

"Librarian Mentoring Program at the University of Utah's J. Willard Marriott Library." University of Utah. Available online at www.lib.utah.edu/mentor/. [Accessed 10 May 2006].

"Mentoring Bibliography for Academic Libraries." Northwestern State University Libraries. Available online at www.nsula.edu/watson_library/acrl/bonnetteAcademicBib.htm. [Accessed 13 August 2004]. Link no longer active July 2007.

"Resources for Mentoring Programs." Mentor. Available online at www.mentoring. org/program_staff/index.php. [Accessed 10 May 2006].

"Truth about Tenure in Higher Education." Higher Education Departments of the National Education Association and the American Federation of Teachers. Available online at www2.nea.org/he/truth.html. [Accessed 22 March 2006].

Allen, Tammy D., Rachel Day, and Elizabeth Lentz. "Role of Interpersonal Comfort in Mentoring Relationships." Journal of Career Development 31, no. 3 (Spring 2005): 155. Ambrose, Larry. Mentor's Companion. 1st ed. Chicago, Ill.: Perrone-Ambrose, 1998.

American Library Association. Association of College and Research Libraries. New Member Mentoring Program. "ACRL New Member Mentoring Program Workbook." Available online at www.ala.org/cfapps/archive.cfm?path=acrl/mentorwb.html. [Accessed 11 November 2004]. Link no longer active July 2007.

Arizona State University Libraries. "K.1: Mentoring Program." Arizona Board of Regents. Available online at www.asu.edu/lib/library/lc/handbook/K1.html. [Accessed 13 August 2004].

Berk, Ronald A., Janet Berg, Rosemary Mortimer, Benita Walton-Moss, and Theresa P. Yeo. "Measuring the Effectiveness of Faculty Mentoring Relationships." Academic Medicine 80, no. 1 (Jan. 2005): 66.

Blake-Beard, Stacy D. "Costs of Living as an Outsider Within: An Analysis of the Mentoring Relationships and Career Success of Black and White Women in the Corporate Sector." Journal of Career Development 26, no. 1 (Fall 1999): 21.

Bonnette, Ashley E. "Mentoring Minority Librarians Up the Career Ladder." Library Administration \& Management 18, no. 3 (Summer 2004): 134. Available online at http:// wilsontxt.hwwilson.com/pdffull/01879/27V46/GS9.pdf. [Accessed 28 July 2004]. 
Brewer, Julie. "Mentoring and Residency Programs for New Librarians." Handout from NCLA (North Carolina Library Association) "Mentoring for Success" Conference, May 16, 2003.

Burich, Nancy J., Frances A. Devlin, and Keith Russell. "Challenges of Developing a Faculty Mentoring Program." Handout of a presentation made at the CULS Fall 2004 Conference, Emporia State University, Emporia, Kansas.

Carter, Mary. "Mentors Inspiring Excellence: NEST New Educator's Support Team." Delta Kappa Gamma Bulletin 70, no. 3 (Spring 2004): 42.

Casto, Challon, Charmaine Caldwell, and Carmen F. Salazar. “Creating Mentoring Relationships. between Female Faculty and Students in Counselor Education: Guidelines for Potential Mentees and Mentors." Journal of Counseling and Development 83, no. 3 (Summer 2005): 331.

Colley, Joanne and Connie Capers Thorson. "Mentoring Along the Tenure Track." College E Research Libraries News 51 (April 1990): 297-300.

Cox, Elizabeth J. "On Being a New Librarian: Eight Things to Keep in Mind." College E Research Libraries News 68, no. 4 (Apr. 2007): 45.

Cunningham, J. Barton. “Using Mentoring for Professional Development.” 1994 Annual: Developing Human Resources (1995): 227-41.

Donaldson, Stewart I., Ellen A. Ensher, and Elisa J. Grant-Vallone. “Longitudinal Examination of Mentoring Relationships on Organizational Commitment and Citizenship Behavior." Journal of Career Development 26, no. 4 (Summer 2000): 233.

Eddy, Erik R., Scott I. Tannenbaum, Steven J. Lorenzet, and Kimberly A. Smith-Jentsch. "Influence of a Continuous Learning Environment on Peer Mentoring Behaviors."” Journal of Managerial Issues 17, no. 3 (Fall 2005): 383.

EDUCAUSE. Mentoring information kit. EDUCAUSE. 2007. Available online at www. educause.edu/mentoring. [Accessed 22 March 2006].

Ensher, Ellen A. and Susan E. Murphy. Power Mentoring: How Successful Mentors and Protégés Get the Most Out of Their Relationships. 1st ed. San Francisco, Calif.: Jossey-Bass, 2005.

Geiger, Adrianne H. "Measures for Mentors." Training \& Development 46, no. 2 (Feb. 1992): 65-68.

Gibson, Sharon. "Being Mentored: The Experience of Women Faculty." Journal of Career Development 30, no. 3 (Spring 2004): 173.

Goetsch, Lori A. "'Mentoring for Research and Publication: Many Roads to the Mountaintop." Printout of a PowerPoint presented to the Nassau County Library Association Academic and Special Libraries Division Annual Staff Development Day, Hofstra University, May 16, 2003. Based on a PowerPoint created by then-editor of Portal: Libraries and the Academy, Gloriana St. Clair. (2003).

Golian-Lui, Linda Marie. "Fostering Librarian Leadership through Mentoring." Adult Learning 14, no. 1 (Winter 2003): 26.

Greene, Timothy J. and Nancy E. Van Kuren. "Preparing for Promotion and Tenure: Facts and Advice on Climbing the Academic Ladder." ASEE Prism 6, no. 7 (Mar. 1997): 26-29.

Haglund, Lotta. "Brief Communication: Mentoring as a Tool for Staff Development." Health Information and Libraries Journal 21, no. 1 (Mar. 2004): 61.

Hambright, W. Grant and Thomas Diamantes. "Analysis of the Experiences of a FirstYear Tenure-Track Faculty Member." Education (Chula Vista, Calif) 124, no. 3 (Spring 2004): 436.

Hansman, Catherine A. "Reluctant Mentors and Resistant Proteges: Welcome to the 'Real' World of Mentoring." Adult Learning 14, no. 1 (Winter 2003): 14.

Hass, V. Heidi and Tony White. "Mentorship Task Force Report, Professional Development Committee, ARLIS/NA." Art Documentation 24, no. 2 (Fall 2005): 49. 
Holloway, John H. “Mentoring New Leaders." Educational Leadership 61, no. 7 (Apr. 2004): 87.

Janas, Monica. "Mentoring the Mentor: A Challenge for Staff Development." Journal of Staff Development 17, no. 4 (Fall 1996): 2.

Kaye, Beverly and Betsy Jacobson. "Mentoring: A Group Guide." Training \& Development 49, no. 4 (Apr. 1995): 22-27

Kem, Carol Ritzen. "Mentoring: A Primer." Chap. 54, in Librarian's Career Guidebook, ed. Priscilla K. Shontz, 463. Lanham, Md.; Toronto; Oxford: Scarecrow Press, Inc., 2004.

Kentucky Library Association. "MAP Guidelines.” Kentucky Library Association. Available online at http://kylibasn.org/mapguide.htm. [Accessed 13 August 2004]. Link no longer active July 2007.

Keyse, Dana, Elizabeth W. Kraemer, and Julie Voelck. "Mentoring Untenured Librarians: All It Takes Is a Little Un-TLC." College \& Research Libraries News 64, no. 6 (2003): 378. Available online at http://wilsontxt.hwweilson.com/pdfful/03836/WDYIT/7SU. pdf. [Accessed 25 August 2004].

Kidd, Jennifer M., Wendy Hirsh, and Charles Jackson. "Straight Talking: The Nature of Effective Career Discussion at Work." Journal of Career Development 30, no. 4 (Summer 2004): 231.

Kuyper-Rushing, Lois. "Formal Mentoring Program in a University Library: Components of a Successful Experiment." Journal of Academic Librarianship 27, no. 6 (Nov. 2001): 440-46.

Landry, Abbie. "Ten Must-Reads for New Academic Librarians." Reference Services Review 33, no. 2 (2005): 228.

Lee, Deborah. "Mentoring the Untenured Librarian: The Research Committee." College and Research Libraries News 66, no. 10 (2005): 711.

- - - "Surviving and Thriving in Academia: A Selective Bibliography for New Faculty Members." Reference Services Review 31, no. 1 (2003): 96.

Lyons, Brian D. and Edward S. Oppler. "Effects of Structural Attributes and Demographic Characteristics on Protege Satisfaction in Mentoring Programs." Journal of Career Development 30, no. 3 (Spring 2004): 215.

Mallard, Kina S. "Soul of Scholarship." New Directions for Teaching and Learning no. 90 (Summer 2002): 59-69.

Mavrinac, Mary Ann. “Transformational Leadership: Peer Mentoring as a Values-Based Learning Process." Portal: Libraries and the Academy 5, no. 3 (2005): 391.

Moody, JoAnn. "Supporting Women and Minority Faculty." Academe 90, no. 1 (Jan.-Feb. 2004): 47-52.

Murphy, Susan E. and Ellen A. Ensher. "Role of Mentoring Support and Self-Management Strategies on Reported Career Outcomes." Journal of Career Development 27, no. 4 (2001): 229.

Petzko, Vicki Nord. "Tayloring Professional Development for a Better Fit." Principal Leadership (Middle School Ed.) 5, no. 3 (Nov. 2004): 16.

Prince, Shelley R. "Magic of Mentoring." Educational Leadership 61, no. 8 (May 2004): 84.

Rochester Regional Library Council. “RRLC Mentoring Program.” Rochester Regional Library Council. Available online at http://rrlc.org/mentor.html [Accessed 13 August 2004]. Link no longer active July 2007.

Rowley, James. “Good Mentor.” Educational Leadership 56, no. 8 (May 1999): 20.

Savage, Hallie, E., Rashelle S. Karp, and Rose Logue. "Faculty Mentorship at Colleges and Universities." College Teaching 51, no. 1 (Winter 2004): 21.

Sawyer, Tom. "Role of the Mentor." Agricultural Education Magazine 77, no. 3 (Nov./Dec. 2004): 16. 
Shea, Gordon F. Mentoring: How to Develop Successful Mentor Behaviors. A Fifty-Minute Series Book. 3rd ed. Menlo Park, Calif.: Crisp Publications, 2002.

Smith, Janice Witt, Wanda J. Smith, and Steven E. Markham. "'Diversity Issues in Mentoring Academic Faculty." Journal of Career Development 26, no. 4 (Summer 2000): 251.

Smith, Wanda J., Jerusalem T. Howard, and K. Vernard Harrington. 2005. Essential Formal Mentor Characteristics and Functions in Governmental and Nongovernmental oOrganizations from the Program Administrator's and the Mentor's Perspective. Public Personnel Management 34, no. 1 (Spring 2005): 31.

Sorcinelli, Mary D. "Principles of Good Practice: Supporting Early-Career Faculty." American Association for Higher Education. Available online at www.aahe.org/ ffrr/principles_brochure2.htm. [Accessed 8 November 2004]. Link no longer active July 2007.

Special Libraries Association. "Mentorship Handbook: A Guide for SLA Chapters and Divisions to Establish Mentorship Programs." Special Libraries Association. Available online at www.sla.org/pdfs/mentorsh.pdf. [Accessed 13 August 2004].

St. Clair, Gloriana. "Editorial: Improving Quality: An Editor's Advice to Authors." College E Research Libraries (May 1993, 1993): 195-97.

Stanley, Christine A. and Yvonna S. Lincoln. "Cross-Race Faculty Mentoring." Change 37, no. 2 (Mar./Apr. 2005): 44.

Swain, Harriet. "Develop a Career-Not a Clone." Times Higher Education Supplement no. 1699 (July 8, 2005): 58.

Thomas, Jerry R. "Vision and Leadership for Selecting and Mentoring New Faculty in Higher Education." Journal of Physical Education, Recreation \& Dance 68, no. 5 (1997): 41-6.

Trubowitz, Sidney. "Why, How, and What of Mentoring." Phi Delta Kappan 86, no. 1 (Sept. 2004): 59.

University of Delaware Library. Assembly of Professional Staff (UDLAPS). "Mentoring Program : Guidelines and Procedures." University of Delaware Library. Available online at www.lib.udel.edu/udlaps/activities/document97.htm. [Accessed 13 August 2004].

University of Georgia Libraries. "Mentor Program: Share What You Know." University of Georgia. Available online at www.libs.uga.edu/mentor/. [Accessed 10 May 2006].

University of Maryland Libraries. "Mentoring Program." University of Maryland Libraries. Available online at www.lib.umd.edu/PASD/LPO/mentoring/. [Accessed 13 August 2004].

Van Avery, Annalisa R. “Facing Personal Evaluation: A Mentoring Program Supports Professional Staff Undergoing Tenure Review." Reference Librarian no. 38 (1992): 121.

Van Slyke, Erik J. and Bud Van Slyke. "Mentoring: A Results-Oriented Approach." HR Focus 75, no. 2 (Feb. 1998): 14.

Wergin, Jon F. "Why We Need Leadership in Place." Department Chair 17, no. 3 (Winter 2007): 1.

Wittkopf, Barbara. Mentoring Programs in ARL Libraries. SPEC Kit 239. Washington, D.C.: Association of Research Libraries, Office of Leadership and Management Services, 1999.

Workman, Gail A. "Mentoring Energizes Mid-Career Mentors." Delta Kappa Gamma Bulletin 71, no. 4 (Summer 2005): 55.

Young, Angela M. and Pamela L. Perrewe. "Role of Expectations in the Mentoring Exchange: An Analysis of Mentor and Protege Expectations in Relation to Perceived Support." Journal of Managerial Issues 16, no. 1 (Spring 2004): 103-126. 


\section{Appendix B. Faculty Mentoring Program Documents}

\section{Appendix B.1. Faculty Mentoring Program.}

Disclaimer. The mentoring program does not remove from the mentee the responsibility for meeting the criteria for promotion and tenure at K-State Libraries. The mentee must be accountable for his/her levels of performance, professional development, research, creativity, and service. The mentee is also accountable for the quality of his/her annual evaluations and portfolios.

Mentors will not be held responsible for the outcome of any personnel actions involving tenure, promotion, or continuing appointment of their mentees.

Purpose. Provide assistance to untenured faculty pursuing their goal of achieving reappointment, tenure and promotion, and help new faculty become familiar with the workings and environment of the Libraries, the University, and the community. This program is not intended (at this point in time) to mentor those wishing to achieve further promotion after tenure. This program is intended to supplement, not replace, the supervisor as the expected mentor of the new faculty member.

Participation. Participation in the program is voluntary for mentors and mandatory for untenured, tenure-track faculty. An individual mentor/mentee relationship may be terminated by either party, in which case a new mentor will be assigned to the mentee by the Professional Development Committee. The mentor/mentee relationship is expected to officially terminate with the attainment of tenure and/or promotion of the mentee (usually about 6 years).

\section{Procedures for the Professional Development Committee}

- Within the first month of employment, the Library Faculty's Professional Development Committee will meet with the new faculty member to learn more about his/her goals, interests, and career plans.

- The Professional Development Committee will then compare what they have learned from the new faculty member to what is known about those who volunteered to be mentors. Realizing that the optimal assignment may not be possible, the Professional Development Committee will assign a mentor to the new mentee. No mentor will have more than 2 mentees during a given academic year.

- The Professional Development Committee will consult with the proposed mentor and the mentee's supervisor prior to making the mentor assignment.

- The Professional Development Committee will inform both the mentor and the mentee of their assignment within 2 weeks of the meeting with the mentee.

- The Professional Development Committee will schedule a meeting with all mentors at least once each quarter to discuss the mentor's experiences and to share ideas. One or more of the Professional Development Committee will be present at these meetings.

- The Professional Development Committee will schedule a meeting with all mentees at least once each quarter to discuss the mentee's experiences and to share ideas. One or more of the Professional Development Committee will be present at these meetings.

- At the discretion of the Professional Development Committee, the mentors and mentees may be contacted to secure feedback.

- In the event that a mentor or mentee wishes to terminate the relationship, the 
individual should contact a member of the Professional Development Committee. Specific reasons for the change should be communicated. Within 4-6 weeks, the Professional Development Committee will determine what course of action will be taken.

- The Professional Development Committee will have the option of using the feedback to assess the success of the program and to report any proposed changes to the Library Faculty.

\section{Guidelines for Mentors and Mentees}

- The mentor and mentee should set a time for their initial meeting within 3 weeks of the assignment.

- By the 3rd get-together, both parties should discuss, agree, and write up their goals for the mentoring relationship for the year. At this same time, both parties should discuss and agree upon a timetable for ongoing contact (not less than once each quarter) and establish time periods to complete the activities that develop from the initial goals.

- Both parties should reach an agreement on the amount of time each can devote to mentoring activities, taking into consideration the needs of the respective departments involved.

- While many of the details of the interactions between mentor and mentee are confidential, both are encouraged to reference these activities in their annual self-evaluations.

\section{Appendix B.2. Criteria for Mentors.}

- Tenured with 3 or more years experience at this Library

- At or above faculty ranking of mentee

- Flexible

- Aware of needs of new professionals

- Skilled in their job responsibilities/respected, well-established

- Active professionally

- Not direct supervisor of mentee

- Not in same department/unit as mentee

- Ability to give effective, constructive critical and positive feedback and to give clear, specific evaluation of progress

- Respectful and appreciative of diversity and possible differences as an individual, in goals and in personal and professional roles

- Approachable

- Willing to make time to mentor

- Objective

- Ability to set realistic goals

- Ability to help mentee and others see when s/he has done a good job

- Willingness to act as a sponsor, ally and/or advocate

- Willingness to be proactive in meeting the needs of the mentee

\section{Appendix B.3. Responsibilities of Mentors.}

These are strongly encouraged

- Formulate, in conjunction with the mentee, a program and schedule tailored to the needs of the mentee/developing the mentee's career in desired ways. Modify if/when needs change.

o Identify professional development activities for mentee such as conferences, committees, publishing opportunities, etc. and introduce mentee to appropriate colleagues, committee chairs, etc. outside the Library 
- Inform mentee of appropriate service opportunities

- Assist mentee in locating resources for service or research activities related to promotion and tenure

- Communicate with the mentee and answer mentee's questions about the calendar for library faculty, the promotion and tenure process, annual review/self-evaluation, and about the portfolios/dossiers

- Arrange, at least quarterly, formal contacts with the mentee during the term of the mentoring relationship to assess progress toward goals. More frequent informal contact is encouraged

- Supplement the mentee's viewpoint with different perspectives outside the narrower departmental view

- Work to establish a true relationship with mentee, talk about your career path, what worked, what didn't, how this may relate to the mentee's career and so on

- Reinforce and assist in the development of a good working relationship between mentee and his/her supervisor

These are required

- Maintain confidentiality of issues discussed with mentee

- Candidly appraise the status of the relationship with mentee and communicate this to the Professional Development Committee

- Attendance at Fall Tenure Workshop

\section{Appendix B.4. Responsibilities of Mentees.}

The mentee must be accountable for his/her levels of performance, professional development, research, creativity, and development. The mentee is also accountable for the quality of his/her annual evaluations and portfolios.

These are strongly encouraged

- Formulate, in conjunction with mentor, a program and schedule tailored to mentee's needs. Modify program and/or schedule if and when needs change.

- Ask specific questions about professional activities, your career and goals, the promotion and tenure criteria and process, the faculty calendar, etc.

- Use your mentor and supervisor to help focus career activities in appropriate ways. Pursue committee opportunities and networking activities suggested by your mentor and participate in any other activities as appropriate.

- Be open to the program; ask questions; keep appointments with mentor.

- Play an active role in the mentoring process - not merely a passive role.

- Be responsive to the interactions/discussions/advice of the mentor.

- Develop a network to meet needs that a sole mentor cannot meet.

- Develop self-awareness at both personal and professional levels.

These are required

- Maintain confidentiality of issues discussed with mentor

- Develop rapport with supervisor and request information from supervisor for departmental issues

- Candidly appraise the status of the relationship with mentor and communicate this to the Professional Development Committee

- Attendance at the Fall Tenure Workshop 


\section{Appendix B.5. Timelines/Calendars for Professional Development Committee}

\begin{tabular}{|l|l|}
\hline \multicolumn{2}{|c|}{ New Tenure-Track Faculty } \\
\hline Dates & Actions for committee \\
\hline D* & Nothing \\
\hline D +30 days & Committee meets with new faculty member \\
\hline D +42 days & Committee meets to determine assignment of mentor \\
\hline D +44 days & Committee informs mentor \& mentee of assignment \\
\hline
\end{tabular}

${ }^{*} \mathrm{D}=$ Start date of new faculty

Calendar of Activities for Professional Development Committee

\begin{tabular}{|l|l|}
\hline Months & Actions for committee \\
\hline August & $\begin{array}{l}\text { Committee meets to plan activities for year: Tenure Workshop, presenta- } \\
\text { tions, etc. }\end{array}$ \\
\hline September & Tenure Workshop \\
\hline October & Meeting with mentors \\
\hline October & Meeting with mentees \\
\hline October & Presentations or seminars?? \\
\hline November & Presentations or seminars?? \\
\hline January & Meeting with mentors \\
\hline January & Meeting with mentees \\
\hline February & Presentations or seminars?? \\
\hline March & Presentations or seminars?? \\
\hline April & Meeting with mentors \\
\hline April & Meeting with mentees \\
\hline April & $\begin{array}{l}\text { Evaluate mentor program. Prepare annual report of activities, suggestions, } \\
\text { etc. for May faculty meeting }\end{array}$ \\
\hline May & Presentations or seminars?? \\
\hline June & Presentations or seminars?? \\
\hline
\end{tabular}

\section{Appendix B.6. Encouraged Mentoring Activities}

- Go to lunch

- Take break together

- Orient to campus, including info/location of McCain, Bramlage, bookstore, meat sale lab, grain science bake sale, recreation center, etc.

- Orient to town, including location of businesses, shopping, schools, clubs/organizations, parks, recreation, etc.

- Inform mentee of local/regional meetings/conferences/workshops which might be of interest

- Inform mentee of community/social activities/events that may be of interest

- Assistance with portfolio/vita 
- Provide introduction/overview of Library and University governance and committees

- Assistance with research, writing and publishing

- Assistance with presentations

- Assistance in selection of additional courses, degree-work, etc.

\section{Appendix B.7. Role of Supervisor in Mentoring Program}

(These are prescriptive)

- Provide a clear statement of expectations for performance in directed and nondirected service and research and creative activities

- Help pre-tenure faculty set challenging but realistic goals for directed and non-directed service and research and creative activities that match the mission and resources of the unit and that align with the central mission of the Libraries

- Formulate, in conjunction with the employee, a program and schedule tailored to the needs of the employee/developing the employee's career in desired ways. Modify if/when needs change.

- Identify professional development activities such as conferences, committees, publishing opportunities, etc. and introduce employee to appropriate colleagues, committee chairs, etc. outside the Library

- Inform of appropriate service opportunities

- Assist in locating resources for service or research activities related to promotion and tenure

- Communicate with the pre-tenure faculty and answer pre-tenure faculty's questions about the calendar for library faculty, the promotion and tenure process, annual review/self-evaluation, and about the portfolios

- Provide feedback to the pre-tenure faculty that highlights what is going well, clarify what needs attention and offer concrete suggestions for improvement through discussions and written comment

- In evaluations, provide clear, honest and constructive feedback.

- Candidly appraise progress toward tenure through discussions and written comment

- Build responsibility for nurturing new colleagues into the evaluations of tenured faculty you directly supervise

- Encourage pre-tenure faculty to be proactive about asking questions, seeking feedback, and making connections with tenured faculty

- Ensure that adequate/basic resources such as office space, equipment, training, etc. are in place

- Encourage pre-tenure faculty to look outside the department/library in seeking collaborative and interdisciplinary opportunities for research and creative activities

- Reinforce and assist in the development of a good working relationship between pre-tenure faculty and his/her mentor

- Attendance at Fall Tenure Workshop 


\section{Appendix C.1. Relationship Profile Questionnaire}

(to be completed by mentor)

\section{Part 1: Description of Relationship}

1. What role(s) did you assume with your mentee in the past year?

$\begin{array}{lll}\text { Teacher } & \text { Counselor } & \text { Advisor _ } \\ \text { Advocate } & \text { Resource } & \text { Other (explain below })\end{array}$

2. How often did you communicate? (e.g., e-mail, in-person, telephone)

3. How long have you had this relationship?

4. How would you characterize the strengths and weaknesses of your relationship?

\section{Part 2: Outcome Measures}

Directions: Please check all of the following that resulted from your interaction with your mentee and specify or describe below. Supporting documents may be attached as appropriate.

1. 1 Publication

2. 1 Presentation or poster

3. 1 Conducting research

4.__ 1 Service activities (e.g., community service, university committee/service, professional committee/service)

5. __ 1 Grant writing/submission

6. 1 Professional expertise

7.___ 1 New method or strategy (in teaching, liaisoning, supervising)

8. 1 New service or extensive revision/expansion of an existing service

9._ 1 Job change/promotion

10. _ 1 Other

\section{Appendix C.2. Relationship Profile Questionnaire}

(to be completed by mentee)

Your Name: Mentor's Name:

\section{Part 1: Description of Relationship}

1. What role(s) did your mentor fulfill in the past year?
_ Teacher Counselor
_ Resource Advisor Sponsor 1 Other (explain below) 1

2. How often did you communicate? (e.g., e-mail, in-person, telephone) 1

3. How long have you had this relationship? 1

4. How would you characterize the strengths and weaknesses of your relationship? 1

\section{Part 2: Outcome Measures}

Directions: Please check all of the following that resulted from your interaction with your mentor and specify or describe below. Supporting documents may be attached as appropriate. 
1. 1 Publication

2. 1 Presentation or poster

3.___ 1 Conducting research

4. __ 1 Service activities (e.g., community service, university committee/service, professional committee/service)

5. 1 Grant writing/submission

6. 1 Professional expertise

7. _ 1 New method or strategy (in teaching, liaisoning, supervising)

8. 1 New service or extensive revision/expansion of an existing service

9._ 1 Job change/promotion

10. _ 1 Other

\section{Appendix C.3. Mentoring Effectiveness}

Mentee name: 1

This is to evaluate the mentoring characteristics of your mentor. Indicate the extent to which you agree or disagree with each statement listed below. Circle the number that corresponds to your response. Your responses will be kept confidential. 1

$\begin{array}{ll}0=\text { Strongly Disagree (SD) } & 3=\text { Slightly Agree (SlA) } \quad 6=\text { Not Applicable (NA) } 1 \\ 1=\text { Disagree (D) } & 4=\text { Agree (A) } 1 \\ 2=\text { Slightly Disagree (SID) } & 5=\text { Strongly Agree (SA) } 1\end{array}$

\begin{tabular}{|l|c|c|c|c|c|c|c|}
\hline & SD & D & SID & SIA & A & SA & NA \\
\hline 1. My mentor was accessible. & 0 & 1 & 2 & 3 & 4 & 5 & 6 \\
\hline 2. My mentor demonstrated professional integrity. & 0 & 1 & 2 & 3 & 4 & 5 & 6 \\
\hline $\begin{array}{l}\text { 3. My mentor demonstrated content expertise } \\
\text { in my area of need. }\end{array}$ & 0 & 1 & 2 & 3 & 4 & 5 & 6 \\
\hline 4. My mentor was approachable. & 0 & 1 & 2 & 3 & 4 & 5 & 6 \\
\hline \begin{tabular}{l} 
5. My mentor was supportive and encouraging. \\
\hline $\begin{array}{l}\text { 6. My mentor provided constructive and useful } \\
\text { critiques of my work. }\end{array}$
\end{tabular} 0 & 1 & 2 & 3 & 4 & 5 & 6 \\
\hline $\begin{array}{l}\text { 7. My mentor motivated me to improve my } \\
\text { performance in my assigned tasks. }\end{array}$ & 0 & 1 & 2 & 3 & 4 & 5 & 6 \\
\hline $\begin{array}{l}\text { 8. My mentor was helpful in providing direc- } \\
\text { tion and guidance on professional issues (e.g., } \\
\text { networking). }\end{array}$ & 0 & 1 & 2 & 3 & 4 & 5 & 6 \\
\hline $\begin{array}{l}\text { 9. My mentor answered my questions satisfacto- } \\
\text { rily (e.g., timely response, clear, comprehensive). }\end{array}$ & 0 & 1 & 2 & 3 & 4 & 5 & 6 \\
\hline $\begin{array}{l}\text { 10. My mentor acknowledged my contribu- } \\
\text { tions appropriately (e.g., committee contribu- } \\
\text { tions, awards). }\end{array}$ & 0 & 1 & 2 & 3 & 4 & 5 & 6 \\
\hline $\begin{array}{l}\text { 11. My mentor suggested appropriate resources } \\
\text { (e.g., experts, electronic contacts, source } \\
\text { materials). }\end{array}$ & 0 & 1 & 2 & 3 & 4 & 5 & 6 \\
\hline $\begin{array}{l}\text { 12. My mentor challenged me to extend my } \\
\text { abilities (e.g., risk taking, try a new profes- } \\
\text { sional activity, draft a section of an article). }\end{array}$ & 0 & 1 & 2 & 3 & 4 & 5 & 6 \\
\hline
\end{tabular}




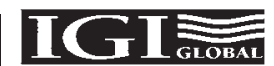

DISSEMINATOR OF KNOWLEDGE

\section{Perpetual Pricing Now Available}

\section{Electronic Business:}

Concepts, Methodologies, Tools, and Applications (4 volumes)

In Lee, Western Illinois University, USA

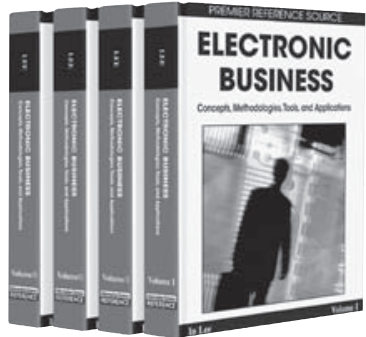

ISBN: 978-1-60566-056-1; 2,586 pp; December 2008 US $\$ 1,650.00$ hardcover

Pre-Pub Price ${ }^{* *}$ : US $\$ 1,550.00$

Perpetual Access: US \$2,475.00

Print + Perpetual: US $\$ 3,300.00$

\section{Database Technologies:}

Concepts, Methodologies, Tools, and Applications (4 volumes)

John Erickson, University of Nebraska, Omaha, USA

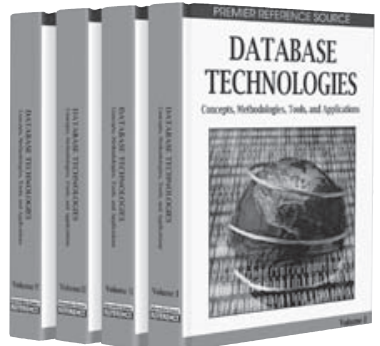

ISBN: 978-1-60566-058-5; 2,692 pp; February 2009 US $\$ 1,650.00$ hardcover

Pre-Pub Price ${ }^{\star *}$ : US $\$ 1,550.00$

Perpetual Access: US $\$ 2,475.00$

Print + Perpetual: US $\$ 3,300.00$

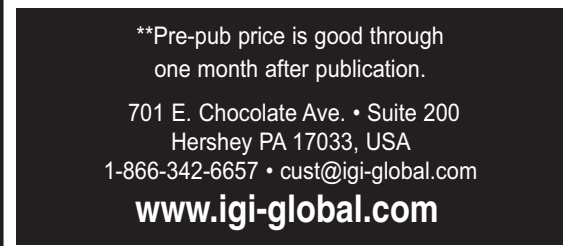

\section{Mobile Computing:}

Concepts, Methodologies, Tools, and Applications (6 volumes)

David Taniar, Monash University, Australia

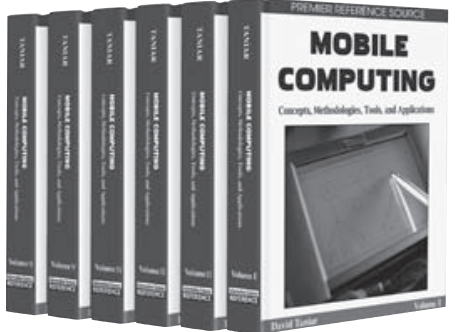

ISBN: 978-1-60566-054-7; 4,142 pp; (C) 2009; Available Now US $\$ 1,950.00$ hardcover

Perpetual Access: US $\$ 2,925.00$

Print + Perpetual: US $\$ 3,900.00$

\section{Medical Informatics:}

Concepts, Methodologies, Tools, and Applications (4 volumes)

Joseph Tan, Wayne State University, USA

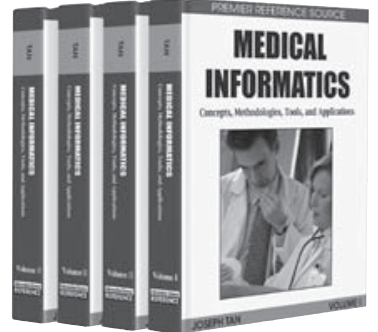

ISBN: 978-1-60566-050-9; 2,772 pp; @ 2009; Available Now US $\$ 2,495.00$ hardcover

Perpetual Access: US $\$ 3,745.00$

Print + Perpetual: US \$4,990.00

Human Computer Interaction: Concepts, Methodologies, Tools and Applications (4 volumes)

Panayiotis Zaphiris and Chee Siang Ang,

City University of London, UK

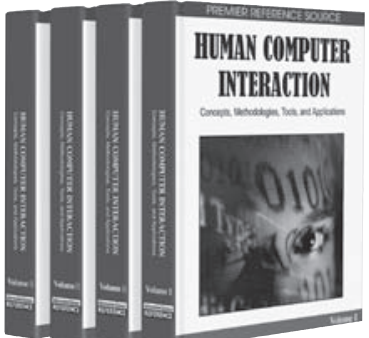

ISBN: 978-1-60566-052-3; 3,024 pp; (C) 2009; Available Now US $\$ 1.650 .00$ hardcover

Perpetual Access: US $\$ 2,475.00$

Print + Perpetual: US \$3,300.00 